\title{
Congenital Hyperinsulinism in Infants with Turner Syndrome: Possible Association with Monosomy X and KDM6A Haploinsufficiency
}

\author{
Christopher E. Gibson ${ }^{a}$ b Kara E. Boodhansingh ${ }^{a}$ Changhong Li ${ }^{a}$ Laura Conlin ${ }^{c, d}$ \\ Pan Chen $^{a}$ Susan A. Becker ${ }^{a}$ Tricia Bhatti ${ }^{b, c}$ Vaneeta Bamba ${ }^{a}$ b N. Scott Adzick ${ }^{e}$ \\ Diva D. De Leon ${ }^{a, b}$ Arupa Ganguly ${ }^{f}$ Charles A. Stanley ${ }^{a, b}$ \\ aDivision of Endocrinology and Diabetes, The Children's Hospital of Philadelphia, Philadelphia, PA, USA; \\ ${ }^{b}$ Department of Pediatrics, The Perelman School of Medicine at the University of Pennsylvania, Philadelphia, PA, USA; \\ 'Department of Pathology and Laboratory Medicine, The Children's Hospital of Philadelphia, Philadelphia, PA, USA; \\ ${ }^{\mathrm{d}}$ Department of Pathology, The Perelman School of Medicine at the University of Pennsylvania, Philadelphia, PA, USA; \\ e Department of Surgery, The Children's Hospital of Philadelphia, The Perelman School of Medicine at the University of \\ Pennsylvania, Philadelphia, PA, USA; ${ }^{\mathrm{f}}$ Department of Genetics, The Perelman School of Medicine at the University of \\ Pennsylvania, Philadelphia, PA, USA
}

\section{Keywords}

Beta cell · Congenital hyperinsulinism · Genetics · Hypoglycemia $\cdot$ Turner syndrome $\cdot \mathrm{X}$ chromosome $\cdot$

Diazoxide $\cdot$ Pancreatectomy

\begin{abstract}
Background: Previous case reports have suggested a possible association of congenital hyperinsulinism with Turner syndrome. Objective: We examined the clinical and molecular features in girls with both congenital hyperinsulinism and Turner syndrome seen at The Children's Hospital of Philadelphia (CHOP) between 1974 and 2017. Methods: Records of girls with hyperinsulinism and Turner syndrome were reviewed. Insulin secretion was studied in pancreatic islets and in mouse islets treated with an inhibitor of KDM6A, an X chromosome gene associated with hyperinsulinism in Kabuki syndrome. Results: Hyperinsulinism was diagnosed in 12 girls with Turner syndrome. Six were diazoxide-unresponsive; 3 had pancreatectomies. The incidence of Turner syndrome among CHOP patients with hyperinsulinism (10 of
\end{abstract}

\begin{tabular}{ll}
\hline KARGER & ( 2018 The Author(s) Karger \\
& Published by S. Karger AG, Basel Open access \\
E-Mail karger@karger.com & This article is licensed under the Creative Commons Attribution- \\
www.karger.com/hrp & $\begin{array}{l}\text { NonCommercial-NoDerivatives 4.0 International License (CC BY- } \\
\text { NC-ND) (http://www.karger.com/Services/OpenAccessLicense). } \\
\text { Usage and distribution for commercial purposes as well as any dis- } \\
\text { tribution of modified material requires written permission. }\end{array}$
\end{tabular}

1,050 from 1997 to 2017) was 48 times more frequent than expected. The only consistent chromosomal anomaly in these girls was the presence of a $45, \mathrm{X}$ cell line. Studies of isolated islets from 1 case showed abnormal elevated cytosolic calcium and heightened sensitivity to amino acid-stimulated insulin release; similar alterations were demonstrated in mouse islets treated with a KDM6A inhibitor. Conclusion: These results demonstrate a higher than expected frequency of Turner syndrome among children with hyperinsulinism. Our data suggest that haploinsufficiency for KDM6A due to mosaic $\mathrm{X}$ chromosome monosomy may be responsible for hyperinsulinism in Turner syndrome.

$$
\begin{aligned}
& \text { ㄷ } 2018 \text { The Author(s) } \\
& \text { Published by S. Karger AG, Basel }
\end{aligned}
$$

\section{Introduction}

Turner syndrome is a common chromosomal disorder affecting 1 in 2,500 live female births that is caused by mosaicism for complete or partial monosomy of the $\mathrm{X}$ chromosome. In addition to classic phenotypic fea-

Charles A Stanley, MD

Division of Endocrinology, The Children's Hospital of Philadelphia

3401 Civic Center Boulevard

Philadelphia, PA 19104 (USA)

E-Mail stanleyc@email.chop.edu 
tures, such as short stature and infertility, Turner syndrome is associated with an increased risk of autoimmune thyroiditis and glucose intolerance and diabetes in adulthood [1-4]; the latter has been ascribed to impaired insulin secretion caused by haploinsufficiency of unknown genes on the $\mathrm{X}$ chromosome $[5,6]$. In addition to these acquired endocrine disorders, several cases of congenital hyperinsulinism in girls with Turner syndrome have been reported [7-11]. Congenital hyperinsulinism is a heterogeneous group of genetic disorders of pancreatic insulin regulation and is the most frequent cause of persistent hypoglycemia in infants and children [12]. Children with some of these disorders respond well to treatment with diazoxide, an activator of the beta-cell ATP-dependent potassium channel, KATP, that is encoded by $A B C C 8$ and $K C N J 11$ on the short arm of chromosome 11; however, cases with KATP mutations that do not respond to diazoxide frequently require pancreatectomy. The reports of hyperinsulinism in girls with Turner syndrome have raised the possibility that $\mathrm{X}$ chromosome anomalies might also be associated with a risk of excessive insulin secretion. Some reports have suggested that an overdosage of $\mathrm{X}$ chromosome material due to the presence of a ring $\mathrm{X}$ chromosome might be responsible for the hyperinsulinism in these cases [9].

The purpose of this report was to analyze the clinical and molecular features of congenital hyperinsulinism of 12 girls with Turner syndrome who were seen at The Children's Hospital of Philadelphia (CHOP) between 1974 and 2017. In addition, studies of insulin secretion were performed in 1 case of Turner syndrome using isolated cultured islets obtained at pancreatectomy. Since inactivating mutations of KDM6A, an autosomal X chromosome gene, have been associated with hyperinsulinism in Kabuki syndrome, we also studied insulin secretion in rodent islets exposed to an inhibitor of KDM6A [13]. Our findings indicate that Turner syndrome occurs more commonly than expected in children with congenital hyperinsulinism and that the mechanism may involve haploinsufficiency for KDM6A on the X chromosome.

\section{Methods}

Subjects included children with congenital hyperinsulinism and Turner syndrome who were referred to CHOP between 1974 and 2017. The diagnosis of hyperinsulinism was based on previously described criteria: fasting hypoglycemia accompanied by inadequate suppression of plasma insulin, inappropriately low plasma beta-hydroxybutyrate and free fatty acid concentrations, and an inappropriate glycemic response to glucagon injection at the time of hypoglycemia [12]. Diazoxide responsiveness was defined by evidence that fasting hypoglycemia could be completely controlled with diazoxide treatment at doses $\leq 15 \mathrm{mg} / \mathrm{kg} / \mathrm{day}$, as demonstrated by maintaining plasma glucose concentration $\geq 70 \mathrm{mg} /$ $\mathrm{dL}$ for $12-18 \mathrm{~h}$ of fasting and developing appropriate hyperketonemia (plasma beta-hydroxybutyrate $>2 \mathrm{mmol} / \mathrm{L}$ ) before plasma glucose dropped to $50 \mathrm{mg} / \mathrm{dL}$. The diagnosis of Turner syndrome was based on clinical findings coupled with complete or partial absence of 1 copy of the X chromosome [1].

\section{Mutation Analysis}

Genomic DNA was isolated from peripheral blood (5 PRIME, Gaithersburg, MD, USA), saliva (Oragene DNA self-collected kit; DNA Genotek, Kanata, ON, Canada), or pancreas (Qiagen, Hilden, Germany). Coding sequences and intron/exon splice junctions for 8 genes known to be associated with hyperinsulinism $(A B C C 8$, KCNJ11, GLUD1, GCK, UCP2, HNF4A, HNF1A, HADH) were amplified and directly sequenced on an ABI 3730 capillary DNA analyzer (Applied Biosystems, Carlsbad, CA, USA). Sequences were analyzed and compared with the published reference sequences. In addition, coding sequences and intron/exon splice junctions for KDM6A, an X chromosome gene known to be associated with hyperinsulinism in Kabuki syndrome, were also amplified, directly sequenced, and analyzed as described above. Determination of the parental origin of the retained $\mathrm{X}$ chromosome was performed using microsatellite markers.

\section{Cytogenetics (SNP Array)}

Genome-wide single-nucleotide polymorphism (SNP) array analysis, including mosaicism estimation, was performed as previously described [14] using Illumina 550k V3 (cases 1-5) and Illumina OmniExpress-8-EXOME arrays (pancreatic DNA from case 3, and case 7) (Illumina, San Diego, CA, USA). SNP arrays were done clinically for cases $6,8,11$, and 12. Cytogenetic (G-banding) analysis was performed by a clinical cytogenetics laboratory (cases 7, 9, 10).

\section{Human Islet Studies}

Pancreatic islets were isolated as described previously [15]. After 2 days of culture in RPMI 1640 with $5 \mathrm{~mm}$ glucose and $10 \%$ fetal bovine serum, islets were perifused with a ramp of amino acid mixture $(0-12 \mathrm{mM})$ or with a ramp of glucose $(0-25 \mathrm{mM})$, followed by $30 \mathrm{mM} \mathrm{KCl}$ at the end of the perifusion. In some experiments, islets were also perifused with $0.3 \mu \mathrm{M}$ glyburide, a KATP channel inhibitor that stimulates insulin release. Islet cytosolic calcium $\left[\mathrm{Ca}^{2+}\right]_{i}$ responses were measured by dual-wavelength fluorescence microscopy using Fura-2AM (Life Technologies) as a calcium indicator (Carl Zeiss Microscopy, Thornwood, NY, USA). Basal $\left[\mathrm{Ca}^{2+}\right]_{i}$ was defined as the average of $\left[\mathrm{Ca}^{2+}\right]_{i}$ in the first $2 \mathrm{~min}$ of perifusion in the absence of fuel after 30-min incubation with Fura-2AM and $5 \mathrm{mM}$ glucose.

\section{Mouse Islet Studies}

Mouse islets were isolated from B6/129/F1 wild-type mice with mixed gender, then cultured for 3 days in RPMI 1640 with $10 \mathrm{mM}$ glucose and $10 \%$ fetal bovine serum in the presence or absence of 5 MM GSK-J1 (Sigma-Aldrich, St. Louis, MO, USA), a highly potent inhibitor of H3K27 histone demethylase, the target of KDM6A. Assay of glucose-stimulated insulin secretion was then performed in batch-incubated islets as described previously [16]. Hand- 
Table 1. Clinical features of 12 girls with Turner syndrome and hyperinsulinism

\begin{tabular}{|c|c|c|c|c|c|c|c|}
\hline Case & Birth weight ${ }^{1}$ & $\begin{array}{l}\text { Age at } \\
\text { hyperinsulinism } \\
\text { presentation }\end{array}$ & $\begin{array}{l}\text { Diazoxide } \\
\text { response }\end{array}$ & Pancreatectomy & $\begin{array}{l}\text { Age at Turner } \\
\text { syndrome } \\
\text { diagnosis }\end{array}$ & $\begin{array}{l}\text { Current } \\
\text { age, } \\
\text { years }\end{array}$ & Current status \\
\hline 1 & $\begin{array}{l}3.1 \mathrm{~kg} \text { at } 37 \text { weeks } \\
\text { (50th-90th percentile) }\end{array}$ & 2 months & - & $90 \%$ at 8.5 months & 10 years & 44 & diabetes at age 32 \\
\hline 2 & $\begin{array}{l}4.0 \mathrm{~kg} \text { at } 42 \text { weeks } \\
\text { (>90th percentile) }\end{array}$ & 1 day & + & - & 6 years & 33 & stopped diazoxide at 2 years \\
\hline 3 & $\begin{array}{l}2.6 \mathrm{~kg} \text { at } 38 \text { weeks } \\
\text { (10th-50th percentile) }\end{array}$ & 2 days & - & $95 \%$ at 18 months & 9 months & 12 & normoglycemic \\
\hline 4 & $\begin{array}{l}3.6 \mathrm{~kg} \text { at } 39 \text { weeks } \\
\text { (>90th percentile) }\end{array}$ & 4 months & - & - & 5 months & 11 & $\begin{array}{l}\text { overnight feeds stopped at } \\
5.5 \text { years }\end{array}$ \\
\hline 5 & $\begin{array}{l}1.5 \mathrm{~kg} \text { at } 34 \text { weeks } \\
(<10 \text { th percentile })\end{array}$ & 1 day & - & - & 8 months & 11 & normoglycemic \\
\hline 6 & $\begin{array}{l}2.5 \mathrm{~kg} \text { at } 39 \text { weeks } \\
\text { (10th-50th percentile) }\end{array}$ & 5 months & + & - & 12 months & 7 & diazoxide stopped at 5.5 years \\
\hline 7 & $\begin{array}{l}3.2 \mathrm{~kg} \text { at } 40 \text { weeks } \\
\text { (50th-90th percentile) }\end{array}$ & 2 days & - & $50 \%$ at 3 months & prenatal & 4 & $\begin{array}{l}\text { limited fasting and continued } \\
\text { overnight feeds }\end{array}$ \\
\hline 8 & $\begin{array}{l}3.2 \mathrm{~kg} \text { at } 38 \text { weeks } \\
\text { (50th-90th percentile) }\end{array}$ & 1 day & - & - & 9 months & 3 & tube feedings and lanreotide \\
\hline 9 & $\begin{array}{l}2.3 \mathrm{~kg} \text { at } 37 \text { weeks } \\
(10 \mathrm{th}-50 \text { th percentile) }\end{array}$ & 1 day & + & - & prenatal & 1 & diazoxide \\
\hline 10 & $\begin{array}{l}1.9 \mathrm{~kg} \text { at } 36 \text { weeks } \\
\text { (10th-50th percentile) }\end{array}$ & 1 day & + & - & 15 days & 1 & diazoxide \\
\hline 11 & $\begin{array}{l}2.4 \mathrm{~kg} \text { at } 36 \text { weeks } \\
\text { (10th-50th percentile) }\end{array}$ & 1 day & + & - & prenatal & 1 & limited fasting \\
\hline 12 & $\begin{array}{l}2.8 \mathrm{~kg} \text { at } 39 \text { weeks } \\
\text { (50th-90th percentile) }\end{array}$ & 7 days & + & - & prenatal & $7 / 12$ & diazoxide \\
\hline
\end{tabular}

${ }^{1}$ Birth weight percentiles based on an Italian nationwide survey of Turner Syndrome patients [17].

picked islets, 5 per well, were preincubated for 30 min with GSK-J1 and then exposed to different concentrations of glucose $(0,2,5,10$, and $25 \mathrm{~mm}$ ) for another $30 \mathrm{~min}$ in the absence of GSK-J1. The supernatant was then collected and insulin was determined by HTRF insulin assay kit (Cisbio Bioassays, Bedford, MA, USA). The $\left[\mathrm{Ca}^{2+}\right]_{i}$ responses of islets from GSK-J1 treated mouse islets to perifusion with glucose were also measured.

\section{Consent}

The study was reviewed and approved by The Children's Hospital of Philadelphia Institutional Review Board. Written informed consent was obtained from the parents of the probands.

\section{Results}

\section{Clinical Features}

As shown in Table 1, a total of 12 girls with Turner syndrome in combination with congenital hyperinsu- linism were seen at CHOP between 1974 and 2017. The median age at presentation of hyperinsulinism was 1 day, with a range from 1 day to 5 months of age. In contrast to the severe hyperinsulinism associated with KATP channel mutations, increased birth weight did not appear to be associated with hyperinsulinism in these girls (binomial proportion test, $p=n s$ ) [17]. The diagnosis of Turner syndrome was not made until after the diagnosis of hyperinsulinism in 8 of the girls; in the other 4 cases, the diagnosis of Turner syndrome was made prenatally, before the presentation of hyperinsulinism.

Six of the girls with Turner syndrome and hyperinsulinism $(6 / 12,50 \%)$ were unresponsive to treatment with diazoxide (cases 1, 3, 4, 5, 7, 8). Three underwent partial or near-total pancreatectomy with histopathology consistent with diffuse hyperinsulinism (cases 1, 3, 7); see Fig- 
Fig. 1. Pancreatic histology of congenital hyperinsulinism in Turner syndrome. a, b Appearance of pancreatic islets in case 3 and case 7 with Turner syndrome and hyperinsulinism. c Pancreas of infant with diffuse KATP hyperinsulinism. d Normal islet in the unaffected region of pancreas from an infant operated on for focal hyperinsulinism. Histopathology of the 2 Turner syndrome cases and the KATP hyperinsulinism case shows similar changes of scattered islet cell nucleomegaly (arrows) and normal lobular parenchymal architecture typical of diffuse hyperinsulinism. HE staining. $40 \times$ magnification.
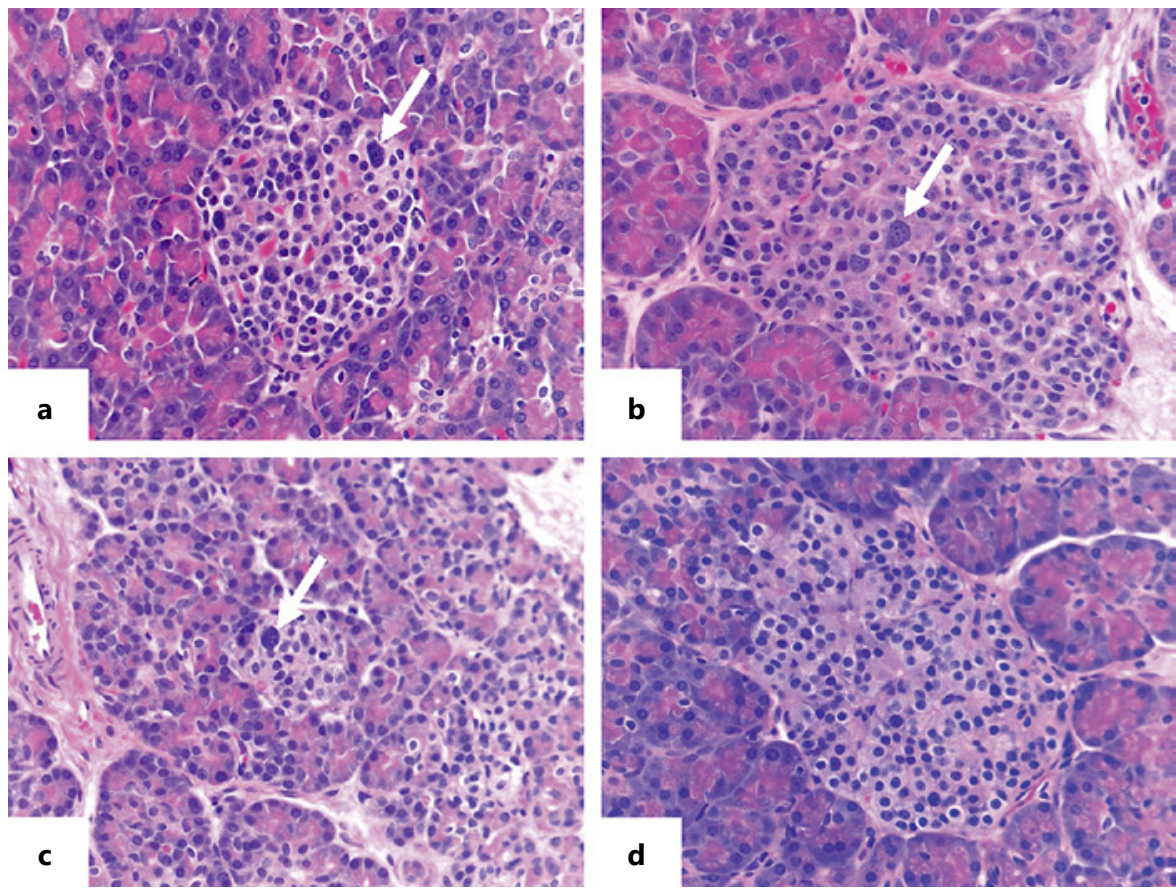

ure 1 . Postoperatively, case 1 continued to have hypoglycemia despite treatment with diazoxide until 5 years of age; she later developed insulin-dependent diabetes at 32 years of age. Case 3 underwent pancreatectomy at 18 months of age with good control of hypoglycemia. Case 7 underwent surgery at 3 months of age and at 4 years of age continues to require treatment for hyperinsulinism, including frequent feedings during the day and continuous overnight feedings. The remaining 3 girls who were unresponsive to diazoxide did not have surgery but were managed with tube feedings and/or frequent oral feedings (cases $4,5,8$ ). Two of these 3 cases are currently 11 years of age and no longer require treatment for hypoglycemia; the third remains on continuous overnight feeding via gastrostomy tube at 3 years of age and recently commenced lanreotide therapy. The remaining 6 girls $(6 / 12$, $50 \%$ ) were diazoxide responsive; cases 9,10 , and 12 continue on diazoxide at ages ranging from 7 to 23 months; cases 2 and 6 were able to discontinue diazoxide between 2 and 5 years of age, without return of hypoglycemia; case 11 was diazoxide responsive, but treatment was discontinued for concern of fluid overload related to an underlying cardiac anomaly and she was managed with frequent oral and tube feedings.

Genetic mutation analysis of genes associated with hyperinsulinism (ABCC8, KCNJ11, GLUD1, GCK, HADH, UCP2, HNF4A, HNF1A) was negative in all cases.

\section{Molecular Features}

As shown in Table 2, cytogenetic analysis revealed that all 12 cases of Turner syndrome with congenital hyperinsulinism had at least 1 cell line that was monosomic for the $\mathrm{X}$ chromosome $(45, \mathrm{X})$. In 5 girls, 45 , X was the only chromosomal anomaly identified in DNA samples from peripheral blood or fibroblasts (cases 2, 3, 7, 11, 12). SNP array analysis of pancreas from case 3 showed a low level mosaicism for a marker X chromosome in $5-15 \%$ of cells (chrX: 51,842,388-97,325,244), while pancreas from case 7 failed to reveal any mosaicism for a second cell line. In addition to a 45,X cell line, 6 of the 12 cases were mosaic for an additional derivative $\mathrm{X}$ chromosome in a proportion of peripheral blood cells or fibroblasts (cases 1, 4, 5, $6,8,9$ ); in 3 of these 6 cases, the marker X chromosome was confirmed to be in a ring conformation by G-banding or FISH (cases $5,6,8$ ). In addition to a $45, \mathrm{X}$ cell line, case 10 was mosaic for a cell line with $3 \mathrm{X}$ chromosomes. A duplication of chromosome 8 was observed in some of the cell lines from case 6 , but there are no genes known to be associated with hyperinsulinism located on chromosome 8. There appeared to be no correlation between the type of X chromosome anomaly and parental origin of the normal X chromosome; we found that patients with both a $45, \mathrm{X}$ or a derivative $\mathrm{X}$ chromosome anomaly demonstrated retention of either the maternal or paternal $\mathrm{X}$ chromosome. As shown in Figure 2, the 7 derivative $\mathrm{X}$
Horm Res Paediatr 2018;89:413-422 DOI: $10.1159 / 000488347$
Gibson et al. 
Table 2. Cytogenetics from peripheral tissue of 12 girls with Turner syndrome and hyperinsulinism

\begin{tabular}{|c|c|c|c|c|c|}
\hline 1 & saliva & 45,X/46,X,der(X) & $57,887,251-81,791,171$ & $80 / 20$ & paternal \\
\hline 2 & blood & $45, \mathrm{X}$ & nil & 100 & unknown \\
\hline 3 & $\begin{array}{l}\text { blood } \\
\text { pancreas }\end{array}$ & $\begin{array}{l}45, X \\
45, X / 46, X, \operatorname{der}(X)\end{array}$ & $\begin{array}{l}\text { nil } \\
51,842,388-97,325,244\end{array}$ & $\begin{array}{l}100 \\
85-95 / 5-15\end{array}$ & $\begin{array}{l}\text { paternal } \\
\text { paternal }\end{array}$ \\
\hline 5 & blood & 45,X/46,X,r(X) & $56,265,083-74,416,032$ & $75 / 25$ & paternal \\
\hline 6 & blood & $45, \mathrm{X} / 47, \mathrm{X}, \mathrm{r}(\mathrm{X}),+8 / 46, \mathrm{X}, \mathrm{r}(\mathrm{X})$ & $27,417,191-5,971,720$ & $30-35 / 15-20 / 65-70$ & maternal \\
\hline 7 & $\begin{array}{l}\text { blood } \\
\text { pancreas }\end{array}$ & $\begin{array}{l}45, \mathrm{X} \\
45, \mathrm{X}\end{array}$ & $\begin{array}{l}\text { not performed } \\
\text { nil }\end{array}$ & $\begin{array}{l}100 \\
100\end{array}$ & $\begin{array}{l}\text { maternal } \\
\text { maternal }\end{array}$ \\
\hline 9 & blood & $\begin{array}{l}\text { 45,X/46,X,+mar/46,X,psu idic }(\mathrm{X}) \\
(\mathrm{p} 11.23) / 47, \mathrm{X}, \mathrm{psu} \operatorname{idic}(\mathrm{X})(\mathrm{p} 11.23) \\
\text { +psu idic }(\mathrm{X})(\mathrm{p} .11 .23)\end{array}$ & not performed & $27 / 33 / 37 / 3$ & unknown \\
\hline 10 & blood & $45, \mathrm{X} / 47, \mathrm{XXX}$ & not performed & $63 / 37$ & unknown \\
\hline 11 & blood & $45, \mathrm{X}$ & nil & 100 & unknown \\
\hline 12 & amniotic fluid & $45, \mathrm{X}$ & nil & 100 & unknown \\
\hline
\end{tabular}

chromosomes that were found ranged in size from $18 \mathrm{Mb}$ (case 5) to $109 \mathrm{Mb}$ (case 9). Case 9 was mosaic for an isodicentric X chromosome. All of these abnormal X chromosomes retained the XIST locus.

A potential candidate gene on the $\mathrm{X}$ chromosome for hyperinsulinism in Turner syndrome is KDM6A, 1 of 2 histone demethylase genes associated with Kabuki syndrome. Hyperinsulinemic hypoglycemia occurs in some cases of both forms of Kabuki syndrome, KS1, due to heterozygous inactivating mutations of KMT2D on $12 \mathrm{q} 13$, and KS2 due to mutations of KDM6A on Xp11.3. Hypoglycemia has been reported to be especially common in KS2 patients with KDM6A mutations [13, 18-27]. Direct mutation analysis of KDM6A was negative in all of the 12 cases in our series; however, all of these girls with Turner syndrome and congenital hyperinsulinism had evidence of mosaic haploinsufficiency of KMD6A due to the presence of at least one 45,X cell line. The KDM6A locus was also absent from 6 of the derivative $\mathrm{X}$ chromosomes, including the isodicentric $\mathrm{X}$ chromosome, but was retained in the derivative $\mathrm{X}$ chromosome in case 6 (Fig. 2).

Congenital Hyperinsulinism in Turner Syndrome

\section{Functional Studies}

Functional studies of insulin secretion were carried out on pancreatic islets isolated from the surgical specimen from Case 7. She was diagnosed with Turner syndrome prenatally and presented with hypoglycemia and seizures on the second day of life. The diagnosis of hyperinsulinism was made at 2 months of age. Genetic mutation analysis failed to identify mutations in any of the known hyperinsulinism genes. She was treated with diazoxide and octreotide without improvement in hypoglycemia. At 3 months of age, she underwent a 50\% pancreatectomy. As shown in Figure 1, the pathology showed increased islet cell nucleomegaly, similar to diffuse hyperinsulinism caused by KATP mutations. Analyses of both peripheral blood and pancreas DNA by SNP array confirmed the prenatal diagnosis of Turner syndrome and showed a 45,X karyotype with no evidence of mosaicism for a marker or ring X chromosome. Following surgery, she continued to require treatment for hypoglycemia with frequent daytime feeds and continuous overnight dextrose; she remains on this regimen at 4 years of age.

Horm Res Paediatr 2018;89:413-422 
Fig. 2. Regions retained on marker X chromosomes in 7 mosaic Turner syndrome girls with congenital hyperinsulinism. Marker X chromosomes ranged in size from $18 \mathrm{Mb}$ (case 5) to approximately 109 $\mathrm{Mb}$ (case 9). Marker X chromosomes were confirmed to be in a ring conformation in cases 5, 6, and 8 (hatched). Case 9 had an isodicentric X chromosome. All abnormal $\mathrm{X}$ chromosomes retained the XIST locus (Xq13.1); only case 6 retained the KDM6A gene locus (Xp11.3).

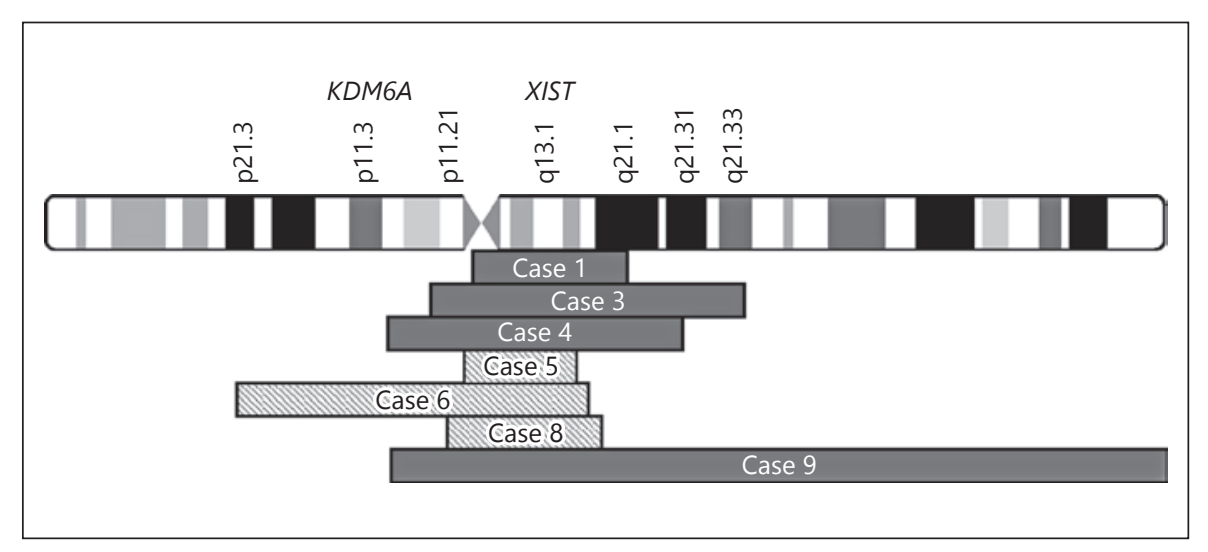

As shown in Figure 3, in vitro studies of pancreatic islets isolated from the surgical specimen of case 7 revealed a distinctive pattern of abnormal responses when compared to either normal human islets or to islets from patients with KATP hyperinsulinism. Basal cytosolic calcium $\left(\left[\mathrm{Ca}^{2+}\right]_{i}\right)$ in islets was elevated to a level that was intermediate between normal control islets isolated from the normal portion of pancreas from a patient with focal hyperinsulinism and that of islets isolated from a patient with typical diffuse hyperinsulinism associated with lossof-function mutations of the KATP channel (Fig. 3a) [28]. Consistent with the increase in basal $\left[\mathrm{Ca}^{2+}\right]_{i}$, basal insulin secretion was elevated in islets from case $7 \mathrm{com}$ pared to normal islets (Fig. 3b, c). Islets from case 7 showed a lower threshold for glucose-stimulated insulin secretion compared to control human islets (2.5 vs. 5.6 $\mathrm{mM}$ ) and demonstrated a prominent "off" response of insulin release following withdrawal of glucose consistent with heightened responsiveness to glucose (Fig. 3c). The islets from case 7 also showed increased sensitivity to stimulation by a mixture of amino acids with a threshold of 6 versus $9 \mathrm{~mm}$ in control islets (Fig. 3b). These abnormal responses to glucose and amino acid stimulation differed from those seen in islets from a patient with hyperinsulinism caused by inactivating mutations of the betacell KATP channel (Fig. 3d), which failed to respond to glucose, but hyper-responded to amino acids (threshold $0.6 \mathrm{mM}$ ). Also, unlike islets from patients with KATP hyperinsulinism which are unresponsive to the KATP channel antagonist glyburide, islets from case 7 with Turner syndrome had a normal response to glyburide (Fig. 3e).

\section{Studies of Insulin Responses to KDM6A Inhibitor in}

Isolated Mouse Islets

In order to determine if decreased expression of $K D M 6 \mathrm{~A}$ could account for the abnormal insulin secretion associated with Turner syndrome, normal mouse islets were treated with the KDM6A inhibitor, GSK-J1, $500 \mathrm{nM}$ for 3 days before examining the response to different concentrations of glucose using batch-incubated islets (Fig. 4). Islets were exposed to the inhibitor for 3 days and then incubated in the absence of inhibitor. As shown in Figure $4 \mathrm{a}$, islets $(n=8)$ that were pretreated with the KDM6A inhibitor showed increased insulin release at 5 and $10 \mathrm{mM}$ glucose stimulation compared to control islets $(n=8)$. This is consistent with the increase in sensitivity to glucose-stimulated insulin secretion that was seen in the perifusion studies of islets from Turner syndrome case 7 (Fig 3c). As shown in Figure 4b, initially after removal from $5 \mathrm{mM}$ glucose, GSK-J1-treated islets $(n=3)$ had elevated basal $\left[\mathrm{Ca}^{2+}\right]_{i}$ compared to control islets $(n=4)$, which was similar to islets isolated from case 7. After a brief period of glucose-free perifusion, $\left[\mathrm{Ca}^{2+}\right]_{i}$ returned to the normal baseline in GSK-J1-treated mouse islets. These data are consistent with the possibility that KDM6A may play a role in the abnormal insulin secretion phenotype of girls with Turner syndrome.

\section{Discussion}

Among the cases of congenital hyperinsulinism seen at $\mathrm{CHOP}$ over a 43 -year period, we identified 12 girls who also had Turner syndrome. In contrast to infants with hyperinsulinism due to mutations of the KATP channel, large for gestational age birth weight did not appear to be a characteristic feature of hyperinsulinism in our Turner syndrome cases. Similar to hyperinsulinism in children with Beckwith Wiedemann syndrome due to paternal $11 \mathrm{p}$ isodisomy, hyperinsulinism in girls with Turner syndrome showed a tendency to resolve during childhood in some cases. All cases were found to have monosomy X in at least a subset of cells. This suggests that haploinsuffi- 


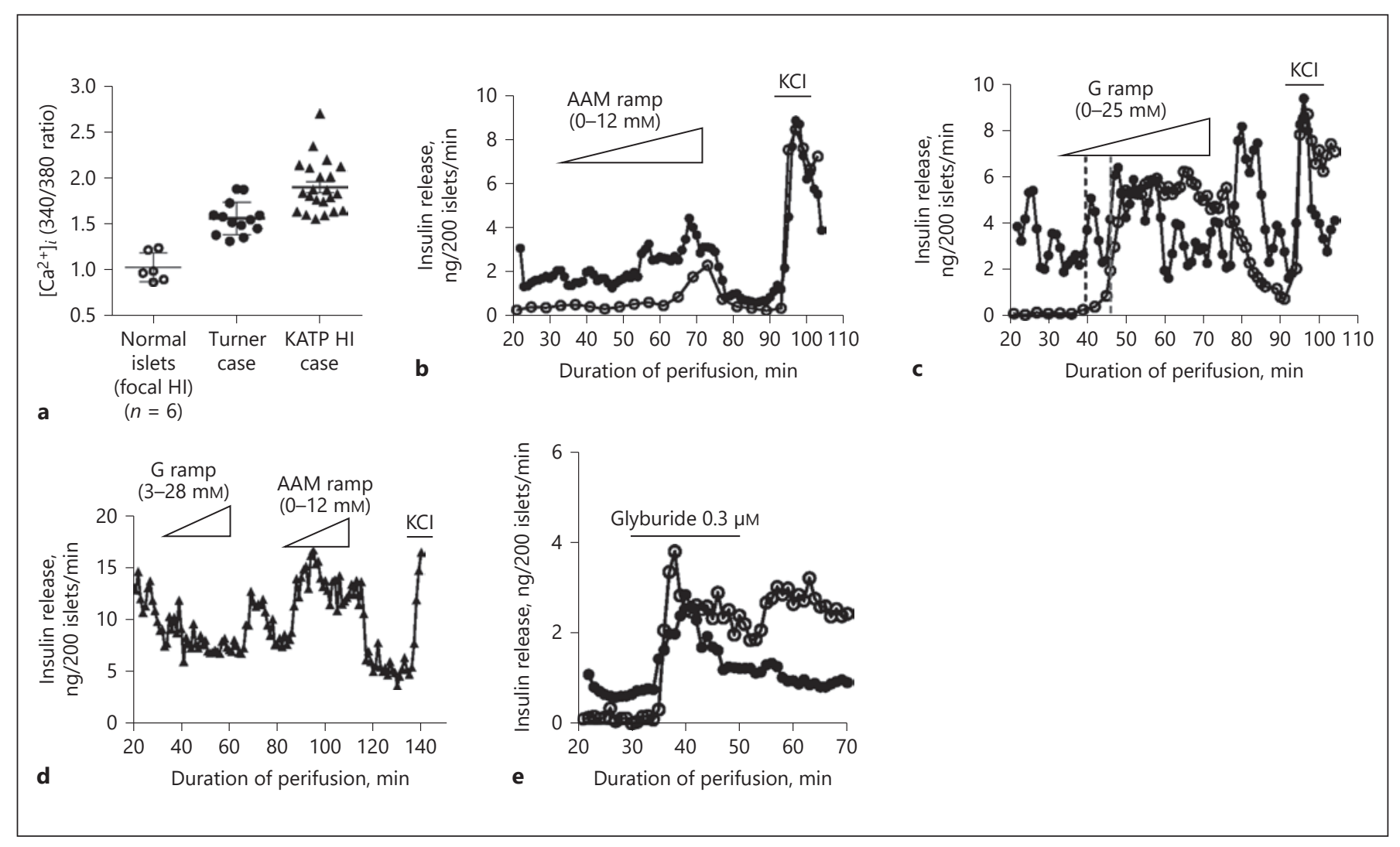

Fig. 3. Functional studies of isolated islets from Turner syndrome case 7. a Basal cytosolic calcium was elevated in islets from case 7 (filled circles) compared to age-matched control islets ( $n=6$, open circles) and similar to islets from a child with loss of function mutations in the KATP gene ABCC8 (filled triangles). Basal calcium measurements from control islets from 6 individuals are shown as averages while the calcium measurements in islets from 1 Turner syndrome case and 1 KATP hyperinsulinism (HI) case are shown as individual islets. Note that basal insulin secretion was also elevated in islets from case 7 compared to control islets $(\mathbf{b}, \mathbf{c})$, similar to the elevation of basal insulin release in islets from a patient with KATP hyperinsulinism (d). b Insulin secretion was stimulated by

ciency for an $\mathrm{X}$ chromosome gene, such as KDM6A, may be responsible for hyperinsulinism associated with Turner syndrome.

The frequency of Turner syndrome among children with hyperinsulinism at CHOP appears to be higher than would be expected if the two disorders were unrelated. Ten of the 12 cases of Turner syndrome with hyperinsulinism were seen after the establishment of the Hyperinsulinism Center at CHOP in 1997 out of a total of 1,050 cases of congenital hyperinsulinism. Assuming that hyperinsulinism occurs equally in both genders, the frequency of Turner syndrome among girls with hyperinsulinism at CHOP equals 1 in 52 (10/525 females) which is an amino acid mixture (AAM) in islets from case 7 and was minimal in control islets. c Insulin secretion was stimulated by a glucose (G) ramp in normal islets and in islets from case 7 (dashed lines indicate threshold concentrations for insulin release: $2.5 \mathrm{mM}$ in case 7 vs. $5.6 \mathrm{~mm}$ in control islets). d Islets from a child with hyperinsulinism due to compound heterozygous inactivating mutations of $A B C C 8$ (c.2222 $+15 \mathrm{c}>\mathrm{a}$ and c.1933delG) responded to stimulation with an amino acid mixture (AAM) ramp, but failed to respond to a glucose (G) ramp. e Insulin secretion was stimulated by glyburide, a KATP channel antagonist, in both control islets and in islets from case 7.

48 times greater than the frequency of Turner syndrome in the general population ( 1 in 2,500 female live births) [1]. This suggests that the risk of hyperinsulinism in girls with Turner syndrome may be increased by about 50 -fold compared to general population estimates of 1 in 40 50,000 , i.e., approximately 1 in 1,000 cases of Turner syndrome [29]. Since the CHOP Hyperinsulinism Center referrals tend to be biased toward more severe cases of hyperinsulinism, it is possible that the latter figure underestimates the incidence of hyperinsulinism in Turner syndrome.

A total of 6 girls with Turner syndrome and congenital hyperinsulinism have been previously reported (Table 3 ) 


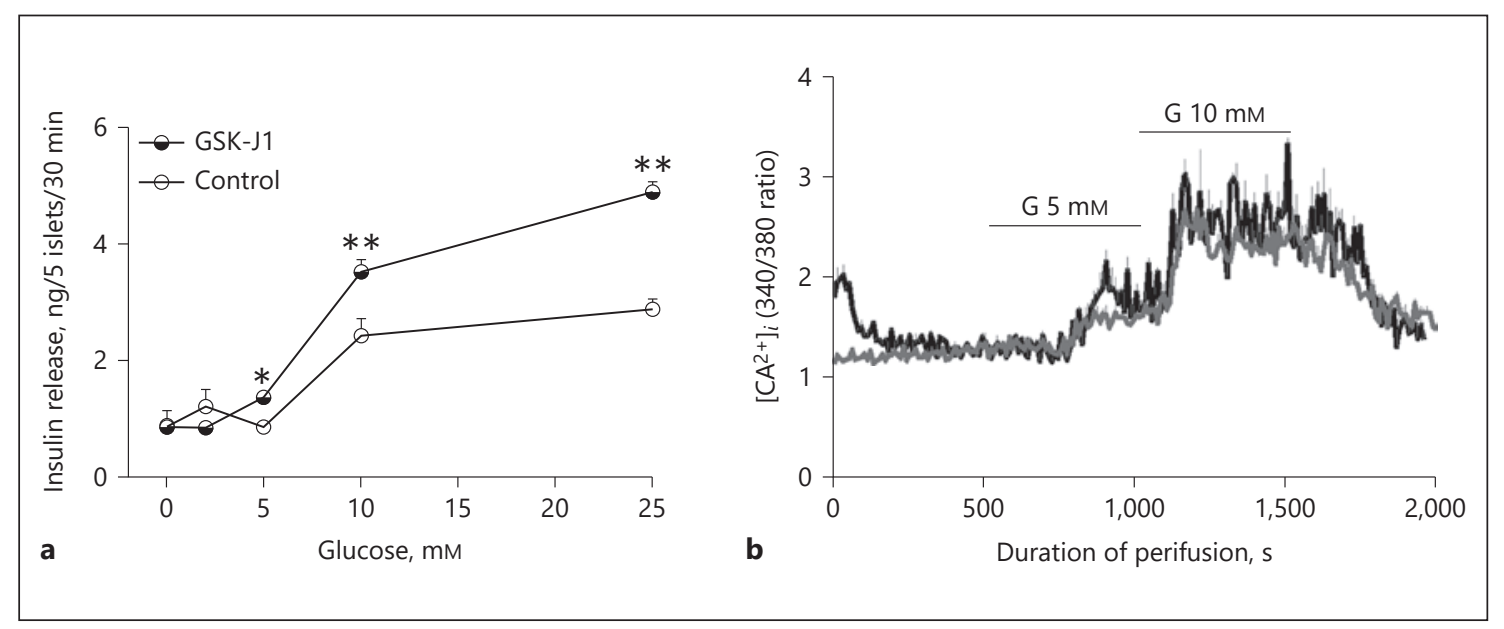

Fig. 4. Effects of a KDM6A inhibitor (GSK-J1) on responses of normal isolated mouse islets. Isolated mouse islets were first cultured with $K D M 6 A$ inhibitor (GSK-J1), $0.5 \mu \mathrm{M}$, for 3 days, removed from GSK-J1 during a 30-min glucose-free preincubation, and then exposed to different concentrations of glucose for another $30 \mathrm{~min}$ in the absence of the inhibitor. a GSK-J1-G SIS-mouse. Islets incubated with GSK-J1 (filled circles) exhibited a leftward shift in glu- cose-stimulated insulin secretion with increased release of insulin at 10 and $25 \mathrm{mM}$ glucose compared to control islets (open circles). ${ }^{*} p<0.05,{ }^{* *} p<0.01$, vs. control. b Basal cytosolic calcium was initially elevated in islets following exposure to GSK-J1 inhibitor (black line) during 3 days of culture, but showed similar cytosolic calcium responses compared to control islets (grey line) during perifusion with 5 or $10 \mathrm{~mm}$ glucose $(\mathrm{G})$ in the absence of GSK-J1.

Table 3. Previous reports of 6 cases with Turner syndrome and hyperinsulinism

\begin{tabular}{lrlll}
\hline Authors [Ref.], year & Age at presentation, days & X chromosome findings & Diazoxide response & Treatment \\
\hline Glassman et al. [7], 1979 & & & & $80 \%$ pancreatectomy \\
$\quad$ Case 1 & 90 & $45, \mathrm{X}$ & - & leucine-restricted diet \\
$\quad$ Case 2 & 120 & $45, \mathrm{X}$ & not tested & corn starch \\
Kizaki et al. [8], 2003 & 1 & $45, \mathrm{X} / 46, \mathrm{X}, \mathrm{r}(\mathrm{X})$ & + & diazoxide \\
Alkhayyat et al. [9], 2006 & 1 & $45, \mathrm{X} / 46, \mathrm{X}, \mathrm{r}(\mathrm{X})$ & + & diazoxide \\
Pietzner et al. [10], 2014 & 1 & $45, \mathrm{X} / 46, \mathrm{X}, \mathrm{r}(\mathrm{X})$ & + & diazoxide \\
Cappella et al. [11], 2015 & 330 & $45, \mathrm{X} / 46, \mathrm{X}, \mathrm{r}(\mathrm{X})$ & & + \\
\hline
\end{tabular}

[7-11]. Three of these cases first presented as neonates. Three of the 6 cases were responsive to diazoxide, but as in our series, some required pancreatectomy. Four of the reported cases had a ring $\mathrm{X}$ chromosome, which has been suggested as a possible factor in hyperinsulinism in girls with Turner syndrome [9]. However, a ring X chromosome was not present in the other 2 reported cases. In contrast, all of the reported cases had at least 1 cell line with complete monosomy $\mathrm{X}(45, \mathrm{X})$ which is consistent with our series of 12 Turner syndrome girls. This suggests that haploinsufficiency for an X chromosome gene, rather than an overdosage of $\mathrm{X}$ chromosome material due to the presence of a ring $\mathrm{X}$ chromosome, may be responsible for the hyperinsulinism in Turner syndrome.
Haploinsufficiency for KDM6A, located on the X chromosome, is an attractive explanation for the occurrence of hyperinsulinism in Turner syndrome. KDM6A escapes $\mathrm{X}$-inactivation and the $\mathrm{Y}$ chromosome homolog is UTY/KDM6C. KDM6A, along with KMT2D (MLL2) on chromosome 12, are associated with Kabuki syndrome, a disorder characterized by short stature and unusual facial features reminiscent of the facial make-up of a Kabuki actor $[13,30,31]$. Several reports have commented on the overlapping features of Turner and Kabuki syndromes, including similarities in their characteristic facial features and short stature $[13,32] . K D M 6 A$ and KMT2D together regulate transcriptionally active chromatin through epigenetic modification of histone $\mathrm{H} 3$ [33]. KDM6A is a ly- 
sine-specific histone $\mathrm{H} 3$ demethylase that controls tissuespecific expression of genes involved in development as well as the cell cycle [34-38]. Loss of function mutations of KDM6A which cause Kabuki syndrome type 2, KS2, are most often somatic mutations [18, 20, 22-25, 27]. Arnoux et al. [39] reported that hypoglycemia occurs in $11 \%$ of Kabuki syndrome patients overall. Recent reports suggest that hypoglycemia may occur in a much higher proportion of patients with KS2 associated with KDM6A mutations $[13,20,22,26]$. The mechanism by which haploinsufficiency for KDM6A causes hyperinsulinism in Kabuki syndrome is not known, but has been suggested to involve disruption of epigenetic changes during pancreatic differentiation $[28,29]$.

The variability in penetrance of hyperinsulinism and responsiveness to diazoxide in Turner syndrome and the differences in phenotype between Turner and Kabuki syndromes might depend to some extent on the fact that the genetic defect in Turner syndrome is mosaic by nature. The proportion of beta cells with monosomy $\mathrm{X}$ in different girls with Turner syndrome is likely to be highly variable and could affect the severity of their hyperinsulinism. Similarly, most patients with Kabuki syndrome have de novo mutations and potential mosaicism for the genetic defect between tissues which could determine variations in phenotypic features. Differences in mosaicism between tissues also appear to explain the variability in severity of hyperinsulinism seen in Beckwith Wiedemann syndrome due to paternal 11p isodisomy [40].

Studies of islets isolated from the pancreas at surgery in 1 of our cases provided a unique opportunity to characterize the islet phenotype of hyperinsulinism in Turner syndrome. These data suggest that hyperinsulinemic hypoglycemia in Turner syndrome is caused by abnormal regulation of insulin secretion. The Turner syndrome islets displayed altered fuel sensing, with increased sensitivity to amino acids and elevated basal cytosolic calcium, somewhat similar to hyperinsulinism associated with KATP channel defects [28]. However, preservation of responses to glucose and glyburide demonstrated that KATP channels were still at least partially functional in the Turner syndrome islets. Studies of mouse islets exposed to an inhibitor of KDM6A reproduced some of the islet phenotype seen in the case of Turner syndrome, supporting the suggestion that haploinsufficiency of KDM6A might be responsible for hyperinsulinism in Turner syndrome. The mechanisms involved in dysregulated insulin secretion in Turner syndrome and in KDM6A deficiency warrant further investigation.

Congenital Hyperinsulinism in Turner Syndrome
Adult women with Turner syndrome are known to have an increased risk of glucose intolerance and type 2 diabetes mellitus, which has been suggested to reflect an insulin secretory defect [5]. Some forms of congenital hyperinsulinism, such as mutations of HNF4A, evolve over time towards hypoinsulinemic diabetes in adulthood [41]. Whether the increased risk of hyperinsulinism in Turner syndrome is related to abnormalities in beta-cell function in adulthood is not known. However, elucidation of the mechanism of hyperinsulinism in girls with Turner syndrome might provide insight into the later risk of diabetes in these women.

In summary, our data indicate that hyperinsulinism occurs approximately 50 times more often than expected in girls with Turner syndrome. In contrast to previous suggestions, the presence of a ring $\mathrm{X}$ chromosome was not consistently associated with hyperinsulinism in Turner syndrome. Our results suggest that haploinsufficiency for an X chromosome gene, specifically KDM6A, may be the cause of hyperinsulinism in Turner syndrome.

\section{Acknowledgements}

This work was supported by National Institutes of Health grant R37-DK056268 (C.A.S.), R01-DK098517 (to C.L. and D.D.L.). Additional support was provided by the CHOP Center for Human Phenomic Science supported by the National Center for Research Resources (grant UL1RR024134) and the National Center for Advancing Translational Sciences (grant UL1TR000003) and the Radioimmunoassay and Islet Cores of the Diabetes Research Center of the University of Pennsylvania Perelman School of Medicine (grant DK19525).

\section{Disclosure Statement}

The authors have nothing to disclose.

References

1 Bondy CA; Turner Syndrome Study Group. Care of girls and women with Turner syndrome: a guideline of the Turner Syndrome Study Group. J Clin Endocrinol Metab. 2007 Jan;92(1):10-25.

2 Gravholt $\mathrm{CH}$, Andersen NH, Conway GS Dekkers OM, Geffner ME, Klein KO et al.; International Turner Syndrome Consensus Group. Clinical practice guidelines for the care of girls and women with Turner syndrome: proceedings from the 2016 Cincinnati International Turner Syndrome Meeting. Eur J Endocrinol. 2017 Sep;177(3):G1-70. 
3 Nielsen J, Wohlert M. Chromosome abnormalities found among 34,910 newborn children: results from a 13-year incidence study in Arhus, Denmark. Hum Genet. 1991 May; 87(1):81-3.

4 Shankar RK, Backeljauw PF. Current best practice in the management of Turner syndrome. Ther Adv Endocrinol Metab. 2018 Jan;9(1):33-40.

5 Bakalov VK, Cooley MM, Quon MJ, Luo ML, Yanovski JA, Nelson LM et al. Impaired insulin secretion in the Turner metabolic syndrome. J Clin Endocrinol Metab. 2004 Jul; 89(7):3516-20.

6 Bakalov VK, Cheng C, Zhou J, Bondy CA. Xchromosome gene dosage and the risk of diabetes in Turner syndrome. J Clin Endocrinol Metab. 2009 Sep;94(9):3289-96.

7 Glassman MS, Schultz RM, MacGillivray MH. Gonadal dysgenesis and leucine-sensitive hypoglycemia. J Pediatr. 1979 Jun;94(6): 930-1.

8 Kizaki ZM, Yoshinda $\mathrm{M}$ et al. A case of severe hypglycemia during infancy turned out to be Turner syndrome with ringed $\mathrm{X}$. Clin Pediatr Endocrinol. 2003;12:69-74.

9 Alkhayyat H, Christesen HB, Steer J, Stewart H, Brusgaard K, Hussain K. Mosaic Turner syndrome and hyperinsulinaemic hypoglycaemia. J Pediatr Endocrinol Metab. 2006 Dec;19(12):1451-7.

10 Pietzner V, Weigel JF, Wand D, Merkenschlager A, Bernhard MK. Low-level hyperinsulinism with hypoglycemic spells in an infant with mosaic Turner syndrome and mild Kabuki-like phenotype: a case report and review of the literature. J Pediatr Endocrinol Metab. 2014 Jan;27(1-2):165-70.

11 Cappella M, Graziani V, Pragliola A, Sensi A, Hussain K, Muratori C et al. Hyperinsulinemic Hypoglycaemia in a Turner Syndrome with Ring (X). Case Rep Pediatr. 2015;2015: 561974.

12 Stanley CA. Perspective on the Genetics and Diagnosis of Congenital Hyperinsulinism Disorders. J Clin Endocrinol Metab. 2016 Mar;101(3):815-26.

13 Lederer D, Grisart B, Digilio MC, Benoit V, Crespin M, Ghariani SC et al. Deletion of KDM6A, a histone demethylase interacting with MLL2, in three patients with Kabuki syndrome. Am J Hum Genet. 2012 Jan;90(1): $119-24$.

14 Conlin LK, Thiel BD, Bonnemann CG, Medne L, Ernst LM, Zackai EH et al. Mechanisms of mosaicism, chimerism and uniparental disomy identified by single nucleotide polymorphism array analysis. Hum Mol Genet. 2010 Apr;19(7):1263-75.

15 Calabria AC, Li C, Gallagher PR, Stanley CA, De León DD. GLP-1 receptor antagonist exendin-(9-39) elevates fasting blood glucose levels in congenital hyperinsulinism owing to inactivating mutations in the ATP-sensitive K+ channel. Diabetes. 2012 Oct;61(10):258591.
16 Li C, Chen P, Palladino A, Narayan S, Russell LK, Sayed S et al. Mechanism of hyperinsulinism in short-chain 3-hydroxyacyl-CoA dehydrogenase deficiency involves activation of glutamate dehydrogenase. J Biol Chem. 2010 Oct;285(41):31806-18.

17 Bernasconi S, Larizza D, Benso L, Volta C, Vannelli S, Milani S et al. Turner's syndrome in Italy: familial characteristics, neonatal data, standards for birth weight and for height and weight from infancy to adulthood. Acta Paediatr. 1994 Mar;83(3):292-8.

18 Armstrong L, Abd El Moneim A, Aleck K, Aughton DJ, Baumann C, Braddock SR et al. Further delineation of Kabuki syndrome in 48 well-defined new individuals. Am J Med Genet A. 2005 Jan;132A(3):265-72.

19 Banka S, Howard E, Bunstone S, Chandler KE, Kerr B, Lachlan K et al. MLL2 mosaic mutations and intragenic deletion-duplications in patients with Kabuki syndrome. Clin Genet. 2013 May;83(5):467-71.

20 Banka S, Lederer D, Benoit V, Jenkins E, Howard E, Bunstone S et al. Novel KDM6A (UTX) mutations and a clinical and molecular review of the X-linked Kabuki syndrome (KS2). Clin Genet. 2015 Mar;87(3):252-8.

21 Banka S, Veeramachaneni R, Reardon W, Howard E, Bunstone S, Ragge N et al. How genetically heterogeneous is Kabuki syndrome?: MLL2 testing in 116 patients, review and analyses of mutation and phenotypic spectrum. Eur J Hum Genet. 2012 Apr;20(4): 381-8.

22 Bögershausen N, Gatinois V, Riehmer V, Kayserili H, Becker J, Thoenes M et al. Mutation Update for Kabuki Syndrome Genes KMT2D and KDM6A and Further Delineation of X-Linked Kabuki Syndrome Subtype 2. Hum Mutat. 2016 Sep;37(9):847-64.

23 Geneviève D, Amiel J, Viot G, Le Merrer M, Sanlaville D, Urtizberea A et al. Atypical findings in Kabuki syndrome: report of 8 patients in a series of 20 and review of the literature. Am J Med Genet A. 2004 Aug;129A(1):64-8.

24 Gohda Y, Oka S, Matsunaga T, Watanabe S, Yoshiura K, Kondoh T et al. Neonatal case of novel KMT2D mutation in Kabuki syndrome with severe hypoglycemia. Pediatr Int. 2015 Aug;57(4):726-8.

25 Gole H, Chuk R, Coman D. Persistent Hyperinsulinism in Kabuki Syndrome 2: Case Report and Literature Review. Clin Pract. 2016 Aug;6(3):848

26 Lindgren AM, Hoyos T, Talkowski ME, Hanscom C, Blumenthal I, Chiang C et al. Haploinsufficiency of KDM6A is associated with severe psychomotor retardation, global growth restriction, seizures and cleft palate. Hum Genet. 2013 May;132(5):537-52.

27 Subbarayan A, Hussain K. Hypoglycemia in Kabuki syndrome. Am J Med Genet A. 2014 Feb;164A(2):467-71.
28 Li C, Ackermann AM, Boodhansingh KE, Bhatti TR, Liu C, Schug J et al. Functional and Metabolomic Consequences of KATP Channel Inactivation in Human Islets. Diabetes. 2017 Jul;66(7):1901-13.

29 Bruining GJ. Recent Advances in hyperinsulinism and the pathogenesis of diabetes mellitus. Curr Opin Pediatr. 1990;2(4):758-65.

$30 \mathrm{Ng}$ SB, Bigham AW, Buckingham KJ, Hannibal MC, McMillin MJ, Gildersleeve HI et al. Exome sequencing identifies MLL2 mutations as a cause of Kabuki syndrome. Nat Genet. 2010 Sep;42(9):790-3.

31 Niikawa N, Kuroki Y, Kajii T, Matsuura N, Ishikiriyama $\mathrm{S}$, Tonoki $\mathrm{H}$ et al. Kabuki makeup (Niikawa-Kuroki) syndrome: a study of 62 patients. Am J Med Genet. 1988 Nov;31(3): 565-89.

32 Bögershausen N, Wollnik B. Unmasking Kabuki syndrome. Clin Genet. 2013 Mar;83(3): 201-11.

33 Aziz A, Liu QC, Dilworth FJ. Regulating a master regulator: establishing tissue-specific gene expression in skeletal muscle. Epigenetics. 2010 Nov-Dec;5(8):691-5.

34 Hong S, Cho YW, Yu LR, Yu H, Veenstra TD, Ge K. Identification of JmjC domain-containing UTX and JMJD3 as histone H3 lysine 27 demethylases. Proc Natl Acad Sci USA. 2007 Nov;104(47):18439-44.

35 Lan F, Bayliss PE, Rinn JL, Whetstine JR, Wang JK, Chen S et al. A histone $\mathrm{H} 3$ lysine 27 demethylase regulates animal posterior development. Nature. 2007 Oct;449(7163):689-94.

36 Wang JK, Tsai MC, Poulin G, Adler AS, Chen $\mathrm{S}$, Liu $\mathrm{H}$ et al. The histone demethylase UTX enables RB-dependent cell fate control. Genes Dev. 2010 Feb;24(4):327-32.

37 Herz HM, Madden LD, Chen Z, Bolduc C, Buff E, Gupta R et al. The H3K27me3 demethylase dUTX is a suppressor of Notchand $\mathrm{Rb}$-dependent tumors in Drosophila. Mol Cell Biol. 2010 May;30(10):2485-97.

38 Hemming S, Cakouros D, Isenmann S, Cooper L, Menicanin D, Zannettino A et al. EZH2 and KDM6A act as an epigenetic switch to regulate mesenchymal stem cell lineage specification. Stem Cells. 2014 Mar;32(3):802-15.

39 De Leon DD, Stanley CA. Congenital Hypoglycemia Disorders: New Aspects of Etiology, Diagnosis, Treatment and Outcomes: Highlights of the Proceedings of the Congenital Hypoglycemia Disorders Symposium, Philadelphia April 2016. Pediatr Diabetes. 2017 Feb;18(1):3-9.

40 Kalish JM, Boodhansingh KE, Bhatti TR, Ganguly A, Conlin LK, Becker SA et al. Congenital hyperinsulinism in children with paternal 11p uniparental isodisomy and Beckwith-Wiedemann syndrome. J Med Genet. 2016 Jan;53(1):53-61.

41 Kapoor RR, Locke J, Colclough K, Wales J, Conn JJ, Hattersley AT et al. Persistent hyperinsulinemic hypoglycemia and maturity-onset diabetes of the young due to heterozygous HNF4A mutations. Diabetes. 2008 Jun;57(6): 1659-63. 